\title{
Direct-to-Consumer-Tests and the Patient-Doctor Relationship. A Survey amongst Users, Non-Users, and Physicians
}

\author{
Martijn N. van Rijswijk ${ }^{2}$ and Theo A. Boer ${ }^{1 *}$ \\ ${ }^{1}$ Protestant Theological University, P.O. Box 11069, NL-9700 CB Groningen and Theologische Universiteit Kampen, Broederweg 15, NL-8261 GS Kampen. \\ ${ }^{2}$ Prof.dr. G.A. Lindeboom Instituut for Medical Ethics, Bergstraat 33, NL-3811 NG Amersfoort.
}

${ }^{*}$ Corresponding author: Theo A. Boer ${ }_{m, 1}$, Professor of Health Care Ethics, Protestant Theological University, Groningen, P.O. Box 11069,9700 CB Groningen; Tel: +31 883371 716; Mobile: +31 63027 6009; Twitter: @theoboer; Email: taboer@pthu.nl

Received: April 29, 2021; Accepted: May 04, 2021; Published: May 12, 2021

\begin{abstract}
In highly developed countries we see an increased uptake of predictive tests that can be accessed without the intervention of a physician. We performed surveys among 1,345 people in order to gauge the experiences and views of users and non-users. Since one of our foci was the impact of taking such tests on patient-doctor relationships, we also interviewed 15 physicians about their views on DTC-test and about their experiences with patients who saw their doctor prior to, or after, taking these tests.

We found that $5.6 \%$ of respondents used DTC-tests, particularly health checks and total body scans, with a tendency to increased use and thus possibly a growth potential. Uptake of DTC-tests was significantly correlated with having a positive attitude towards DTC-tests, male gender, and younger age in our main analysis, and with a positive attitude in our most representative subgroup analysis. In accordance with other studies, we found little evidence of a positive impact of DTC-participation that could not have been reached by other means. Generally, DTC-tests had a neutral to positive influence on patient-doctor relationships. GPs and consumers agree that that participation in DTC-tests, irrespective of physicians' views on their value, should not inhibit existing patient-doctor relationships. This means that GPs may need an upgrade in their knowledge of DTC-tests.
\end{abstract}

Keywords: Health checks, Predictive tests, Direct to Consumer tests, DTC-tests, Screening, Patient-doctor relationship, ethics, Netherlands

\section{Introduction}

Predictive medicine aims at early detection of disease or at identifying persons who are at risk of developing a disease, preferably in presymptomatic and well-treatable stages. It signifies a shift from a predominantly reactive to a more proactive medicine [1-3]. It particularly aims at various types of cancer and cardiovascular conditions, which often encompass several stages of disease: from asymptomatic to overtly symptomatic [4]. Due to an increase in knowledge of (asymptomatic) stages of disease and a widening range of tests--including blood tests for markers of disease, radiological imaging such as CT- or MRI-screening [5-7], genetic tests, and measurement of physical parameters such as blood pressure-the uptake of predictive medicine can be expected to rise in coming decades. In the Netherlands, predictive tests need governmental approval when they involve potentially harmful means (i.e. radiation) or when they target non-preventable and non-treatable diseases (e.g. Huntington's disease). Screening criteria formulated by Wilson and Jungner play an important role in the approval procedure [4]. All DTC-tests are subject to general legal requirements with regard to safety, transparency, and informed consent.

In the Netherlands, some predictive tests that fulfil these criteria are offered as governmental screening programs for pre- defined high-risk groups, depending on their cost-benefit analysis. Currently, there are governmentally offered blood and ultrasound tests during pregnancy; blood and hearing checks for neonates; and screening programs for breast-, cervix-, and bowel cancer in adults. These tests assume an abstract relationship between institutions and individuals at risk, who are invited to undergo a particular test if they fall within a particular risk group. Other predictive tests are part of the diagnostic apparatus of the regular healthcare system $[8,9]$. Here, they presuppose a patient-doctor relationship, starting with a patient addressing their professional with a health-related question. In liaison with the patient, the healthcare professional will refer the patient for further medical investigations if indicated according to clinical guidelines, expert opinion, or for other reasons. In the Dutch context this is often a general practitioner (GP), often also known as 'family doctor' with whom there is a long-standing patient-doctor relationship. Both governmental screening programs and tests within the regular healthcare system involve a third-party (government or physician) that selects potential participants.

In contrast to the above, some tests do not involve a third-party selecting individuals for inclusion: tests that have become publicly available through insurance companies, pharmacies, NGOs, employers, and sport clubs $[10,11]$. We refer to these tests as direct-to-consumer (DTC) tests. Medically and ethically, DTC-tests are interesting for 
several reasons. First, they may influence a patient's wellbeing: they may reduce anxiety and fear for the unknown, provide knowledge of treatable and preventable diseases, and encourage healthier lifestyles [7]. They may also cause harm, either due to the test itself, but also secondary as a consequence of additional and sometimes unnecessary investigations or treatments. DTC-tests may also increase anxiety and fear due to uncertain or false-positive test results [6,12]. Second, DTCtests may have positive consequences for the accessibility and fair distribution of healthcare. Early detection and appropriate treatment may reduce the need for expensive medical treatment at later stages of disease, possibly reducing the strain on publicly funded healthcare systems. However, they may also negatively influence accessibility and fair distribution of healthcare, as they may involve unnecessary tests and therapies and cause a health gap between those who can and who cannot afford testing. Third, DTC-tests fit into a pattern of an increased emphasis on patient autonomy, shifting from paternalistic to patient-oriented approaches of medicine [13].

Although interesting medically and ethically, there are several knowledge gaps. First, there is scarce data on the uptake of DTCtests in general, characteristics of users of DTC-tests, and reasons for participation in DTC-tests. Further, to our knowledge there is no literature on the implications of DTC-tests for patient-doctor relationships. The research presented here addresses these voids. We will first map the incidence of the use of DTC-tests amongst respondents, explore the characteristics of users and non-users of DTC-tests, and investigate reasons for (non)participation. We then concentrate on the impact of DTC-tests on the patient-doctor relationship. Here, we focus on the involvement of physicians prior to and after a patient undergoes a DTC-test; on the view of DTCtests held by users, non-users, and GPs; on the response of physicians when a patient did undergo a DTC-test; and on how this response was perceived by users. Further, we explore the follow-up of a DTCtest, and the morally relevant consequences testing may have on the patient-doctor relationship.

The normative hypothesis of this research is that participation in DTC-tests enhances patient autonomy and challenges existing patient-doctor relationships by bypassing the need for a physician's expertise and referral.

\section{Methods}

\section{Study design and population}

This study has a cross-sectional survey design, with online, structured questionnaires among users and non-users of DTCtests, and semi-structured interviews among GPs. The results were discussed in a focus group of users, non-users, and GPs.

\section{The questionnaires}

Three ethical frameworks were used to identify morally relevant aspects of DTC-tests and their potential impact on patient-doctor relationships: Beauchamp and Childress' principalist approach in biomedical ethics [14], Wilson and Jungner's principles of screening [4], and Emanuel and Emanuel's models of the patient-doctor relationship. The first contains the principles of autonomy, beneficence, non-maleficence, and justice. Wilson and Jungner's principles weigh the effectiveness of a particular test considering a disease's prevalence, severity, and treatability, and a test's effectivity, necessity, acceptability, and cost-benefit analysis. Values that underlie their principles are nonmaleficence, beneficence, and justice. Finally, Emanuel and Emanuel's four models of the patient-doctor relationship help us to understand the interactions of patient autonomy and the physician's responsibility [13]. In the traditional or paternalistic model the physician has a leading role in promoting wellbeing with patient autonomy playing a marginal role. In the informative model, patient autonomy is leading. The other models are situated between these extremes, allowing room for shared decision-making: the interpretative model resembles the informative model but stresses the physician's role in helping the patient interpret their underlying beliefs and values without influencing the process of deliberation; in the deliberative model the physician not only helps interpreting but also engages in a process of critical deliberation with the patient.

From the exploration of these normative aspects, we proceeded towards composing research questionnaires. Questions about respondents' attitudes towards and uptake of DTC-tests are mainly based on the value of autonomy. Questions on their reasons for (not) participating and reasons for (not) consulting a physician involve all four principles of biomedical ethics. Beneficence and non-maleficence were the point of focus of questions about the effects of participation on the health and relationships of DTC-users. How respondents view and value their patient-doctor relationship was explored in questions about whether users informed their physician before or after testing, their reasons for (not) consulting, and their experiences if they did consult their physician. Further, all four ethical principles and the typology of the patient-doctor relationship underlie a number of statements that were presented to users and non-users.

\section{Data collection methods and sampling techniques}

Our survey of users and non-users was performed among two research groups: members from the Nederlandse Patiënten Vereniging (NPV), the largest patient association in the Netherlands, which has a predominantly Protestant Christian background; and members of research agent Direct Research (DR), forming a more general representation of the Dutch population.

Questionnaires received from 1345 users and non-users focused on their participation in and attitude towards DTC-tests. Non-users where asked about the reasons for not participating, users about the reasons to participate, the type of DTC-tests they underwent (total body scan, genetic testing, or other health checks), the consequences of participation for themselves or their relatives, whether they informed their relatives about the results, whether they consulted a physician before or after testing and the reasons for (not) consulting, how they experienced different aspects of their doctor's involvement, how participation influenced their patient-doctor relationship, and if they would advise DTC-tests to others. All respondents were presented statements concerning their physician's knowledge of and attitude to DTC-tests, the influence of testing on patient-doctor and family relations, their willingness to undergo testing in the future, and whether DTC-tests should be encouraged, with options ranging from 'totally disagree' to 'totally agree.' 
General physicians were recruited through the researchers' networks, the network of the study's supervisory board, and social media. They were interviewed with the use of semi-structured questionnaires matching the content of the questionnaires sent to users and non-users. After 13 interviews, saturation[15] was reached. In total, 15 GPs were interviewed.

For our discussion section, we used the results of a focus group discussion consisting of two DTC-users (one of which was a medical specialist), one non-user, and two GPs. A fictitious case of a DTC-user who underwent a total body scan and visits his GP, worried about the results of the scan, was presented to members of the focus group.

\section{Data analysis}

Data of baseline characteristics and outcomes are presented as absolute numbers and proportions. Characteristics of NPV- and DRrespondents, and users and non-users, were compared using Pearson's chi-squared test or Fisher's exact test. For variables with more than 2 categories, additional pairwise comparisons were done for each category if the overall chi-squared or Fisher's exact test was significant.

Next, univariate and multivariate logistic regression analyses between predictor variables (baseline characteristics) and the outcome variable, uptake of DTC-tests, were performed for all participants, and separately for NPV- and DR-participants. Data are presented as adjusted Odds Ratios (aORs) with their respective confidence intervals (CIs) and related significance. To enhance comparability, for each variable similar reference groups were used. For our multivariate analyses, we included only significant predictor variables of univariate logistic regression. To prevent overfitting, for each predictor variable at least 10 events-DTC-users-were required. Interactions between predictor variables were tested using interaction terms. Multicollinearity was tested by calculating Variable Inflation Factors (VIFs). If VIF $>10$, multicollinearity between predictor variables was assumed and consequently, variables were removed from multivariate analysis. Further, Box-Tidwell models were used to check the linearity assumption.

For all survey analyses, initial significance levels were set at an alpha-level of 0.05 . In case of multiple pairwise comparisons, Bonferroni-corrections were applied to adjust alpha-levels. Our surveys among GPs had qualitative and heuristic purposes. Therefore, no statistical analyses were performed.

\section{Results}

\section{Survey amongst users and non-users}

\section{Baseline characteristics}

Baseline characteristics and uptake of DTC-tests of NPVparticipants $(\mathrm{N}=1029 ; 76.5 \%$ of total participants $)$ compared to DR-participants $(\mathrm{N}=316 ; 23.5 \%)$ can be found in table 1a; baseline characteristics of users $(\mathrm{N}=75 ; 5.6 \%$ of total participants) compared to non-users $(\mathrm{N}=1270 ; 94.4 \%)$ can be found in table $1 \mathrm{~b}$. Two participants who assumed themselves users participating in governmental screening programs, were reclassified as non-users as these do not qualify as DTC-tests. Therefore, data of 2 non-users are partly missing.
Comparing NPV- to DR-groups, participants of the NPVgroup were significantly more likely to be male, of older age, and of a higher educational background. Further, as expected, they were more likely to be Protestant Christians, and less likely to be Roman Catholic, Humanistic, or non-religious. Regarding DTC-tests, NPVparticipants were less likely to have a positive or mixed attitude and more likely to be negative. Further, NPV-participants were less likely to have undergone DTC-tests. Looking at the type of DTC-test among users, NPV-participants were less likely to have had total body scans. There were no significant differences in the uptake of genome testing or other health checks between DTC-users in NPV- and DR-groups.

Comparing users to non-users, users were more likely to be male, of younger age, and non-religious. Comparing attitudes, users were more likely to be positive and less likely to be negative towards predictive medical tests.

\section{Outcomes of users}

Table 2 shows outcomes of users regarding the type and timing of DTC-testing, reasons for participation, information regarding consultation of one's physician, and consequences of testing for users and their relatives. In total, 75 individuals underwent DTCtests, of whom most within the last 5 years $(\mathrm{N}=52,69.3 \%)$. Of users, 18 underwent a total body scan (24.0\%), 3 underwent genetic testing (4.0\%), and 54 underwent another health check (72.0\%), such as periodic occupational health tests $(\mathrm{N}=15)$, blood tests for several blood markers such as cholesterol and blood glucose $(\mathrm{N}=$ $8)$, musculoskeletal tests $(\mathrm{N}=5)$, tests for cardiac disease $(\mathrm{N}=2)$, and general preventive health tests not further explicated $(\mathrm{N}=11)$. Reasons for participation were an offer by their employer (29.3\%), out of curiosity (25.3\%), presence of symptoms (21.3\%), family medical history (16.0\%), and out of concern (10.7\%).

Before testing, 14 users (18.7\%) consulted their physician. Nine of these found their doctor to have a positive attitude towards testing (64.3\%), and six were informed by their physician on the pros and cons of testing (42.9\%). Only one user found their physician to be dissuading (7.1\%). Sixty-one users $(81.3 \%)$ did not consult their general physician before testing, the majority stating they did not need their physician to decide on testing $(\mathrm{N}=38,62.3 \%)$. Two users (3.3\%) assumed their physician would oppose testing. After testing, 21 users (28.0\%) consulted their physician, with main reasons being that they needed medical follow-up (42.9\%), reassurance $(33.3 \%)$, or wanted to inform their doctor (23.8\%). Fifty-four users (72.0\%) did not consult their physician after testing, mostly because no medical follow-up was needed $(53.7 \%)$ or they did not need their physician (35.2\%). Two of $54(3.7 \%)$ did not consult their doctor because they thought their physician would oppose testing.

Main consequences of testing for users were better insight in health risks (42.7\%), lifestyle changes (36.0\%), and reassurance about one's health $(26.7 \%)$. Five users needed further examining $(6.7 \%)$ and 8 received medical treatments $(10.7 \%)$. One user became more concerned about their health (1.3\%). Sixty users informed their relatives on the results $(80.0 \%)$, of which 6 noticed consequences for their relatives, mainly lifestyle changes and better insight in their health risks. 
Table 1a: Baseline characteristics Comparing research groups

\begin{tabular}{|c|c|c|c|c|}
\hline & $\begin{array}{c}\text { NPV } \\
(N=1029)\end{array}$ & $\begin{array}{c}\text { DR } \\
(\mathrm{N}=316)\end{array}$ & P-value & $\begin{array}{c}\text { Total } \\
(\mathrm{N}=1345)\end{array}$ \\
\hline Male, $\mathrm{N}$ (\% of total in group) & $410 / 1029(39.8 \%)$ & $159 / 316(50.3 \%)$ & $\mathrm{P}=0.001^{*}$ & $569 / 1345(42.3 \%)$ \\
\hline 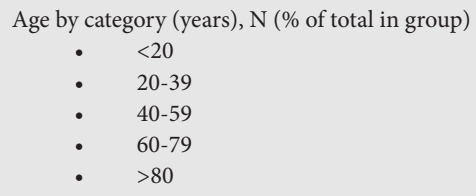 & $\begin{array}{c}4 / 1029(0.4 \%) \\
53 / 1029(5.2 \%) \\
401 / 1029(39.0 \%) \\
534 / 1029(51.9 \%) \\
37 / 1029(3.6 \%)\end{array}$ & $\begin{array}{c}2 / 316(0.6 \%) \\
115 / 316(36.4 \%) \\
118 / 316(37.3 \%) \\
81 / 316(25.6 \%) \\
0 / 316(0.0 \%)\end{array}$ & $\begin{array}{l}\mathrm{NS}^{* *} \\
\mathrm{P}=0.000^{*} \\
\mathrm{NS}^{*} \\
\mathrm{P}=0.000^{*} \\
\mathrm{P}=0.001^{*}\end{array}$ & $\begin{array}{c}6 / 1345(0.5 \%) \\
168 / 1345(12.5 \%) \\
519 / 1345(38.6 \%) \\
615 / 1345(45.7 \%) \\
37 / 1345(2.8 \%)\end{array}$ \\
\hline $\begin{array}{cl}\text { Level of education, } \mathrm{N} \text { (\% of total in group) } \\
\text { • } & \text { Low } \\
\text { - } & \text { Middle } \\
\text { • } & \text { High } \\
\text { - } & \text { Other education }\end{array}$ & $\begin{array}{c}124 / 1029(12.1 \%) \\
437 / 1029(42.5 \%) \\
468 / 1029(45.5 \%) \\
0 / 1029(0.0 \%)\end{array}$ & $\begin{array}{c}75 / 316(23.7 \%) \\
130 / 316(41.1 \%) \\
108 / 316(34.2 \%) \\
3 / 316(1.0 \%)\end{array}$ & $\begin{array}{l}\mathrm{P}=0.000^{*} \\
\mathrm{NS} \\
\mathrm{P}=0.000^{*} \\
\mathrm{NS}^{* *}\end{array}$ & $\begin{array}{c}199 / 1345(14.8 \%) \\
567 / 1345(42.2 \%) \\
576 / 1345(42.8 \%) \\
3 / 1345(0.2 \%)\end{array}$ \\
\hline 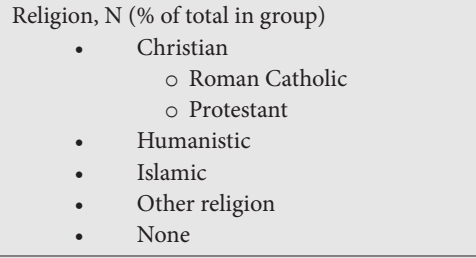 & $\begin{array}{c}993 / 1029(96.5 \%) \\
14 / 1029(1.4 \%) \\
979 / 1029(95.1 \%) \\
1 / 1029(0.1 \%) \\
0 / 1029(0.0 \%) \\
29 / 1029(2.8 \%) \\
6 / 1029(0.6 \%)\end{array}$ & $\begin{array}{c}124 / 316(39.2 \%) \\
60 / 316(19.0 \%) \\
64 / 316(20.3 \%) \\
13 / 316(4.1 \%) \\
2 / 316(0.6 \%) \\
13 / 316(4.1 \%) \\
164 / 316(51.9 \%)\end{array}$ & $\begin{array}{c}\mathrm{P}=0.000^{*} \\
\mathrm{P}=0.000^{*} \\
\mathrm{P}=0.000^{*} \\
\mathrm{P}=0.000^{* *} \\
\mathrm{NS}^{* *} \\
\mathrm{NS}^{*} \\
\mathrm{P}=0.000^{*}\end{array}$ & $\begin{array}{c}1117 / 1345(83.1 \%) \\
74 / 1345(5.5 \%) \\
1043 / 1345(77.6 \%) \\
14 / 1345(1.0 \%) \\
2 / 1345(0.2 \%) \\
42 / 1345(3.1 \%) \\
170 / 1345(12.6 \%)\end{array}$ \\
\hline $\begin{array}{cl}\text { Attitude, } \mathrm{N} \text { (\% of total in group) } \\
\text { - } \quad \text { Mainly positive } \\
\text { - } & \text { Positive and negative } \\
\text { - } & \text { Mainly negative } \\
& \text { No opinion }\end{array}$ & $\begin{array}{c}37 / 1029(3.6 \%) \\
639 / 1029(62.1 \%) \\
311 / 1029(30.2 \%) \\
42 / 1029(4.1 \%)\end{array}$ & $\begin{array}{c}28 / 316(8.9 \%) \\
226 / 316(71.5 \%) \\
49 / 316(15.5 \%) \\
13 / 316(4.1 \%)\end{array}$ & $\begin{aligned} \mathrm{P}= & 0.000^{*} \\
\mathrm{P}= & 0.002^{*} \\
\mathrm{P}= & 0.000^{*} \\
& \mathrm{NS}^{*}\end{aligned}$ & $\begin{array}{c}65 / 1345(4.8 \%) \\
865 / 1345(64.3 \%) \\
360 / 1345(26.8 \%) \\
55 / 1345(4.1 \%)\end{array}$ \\
\hline 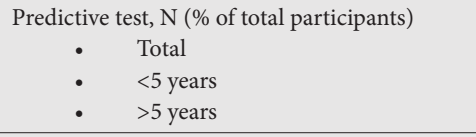 & $\begin{array}{l}42 / 1029(4.1 \%) \\
31 / 1029(3.0 \%) \\
11 / 1029(1.1 \%)\end{array}$ & $\begin{array}{c}33 / 316(10.4 \%) \\
21 / 316(6.7 \%) \\
12 / 316(3.8 \%)\end{array}$ & $\begin{array}{l}\mathrm{P}=0.000^{*} \\
\mathrm{P}=0.003^{*} \\
\mathrm{P}=0.001^{*}\end{array}$ & $\begin{array}{l}75 / 1345(5.6 \%) \\
52 / 1345(3.9 \%) \\
23 / 1345(1.7 \%)\end{array}$ \\
\hline $\begin{array}{cl}\text { Type of predictive test, } \mathrm{N} \text { (\% of total in group) } \\
\text { - } \quad \text { Total body scan } \\
\text { - } \quad \text { Genome testing } \\
\text { Other health check }\end{array}$ & $\begin{array}{c}7 / 1029(0.7 \%) \\
1 / 1029(0.1 \%) \\
34 / 1029(3.3 \%)\end{array}$ & $\begin{array}{l}11 / 316(3.5 \%) \\
2 / 316(0.6 \%) \\
20 / 316(6.3 \%)\end{array}$ & $\begin{array}{c}\mathrm{P}=0.001^{\star *} \\
\mathrm{NS}^{\star *} \\
\mathrm{NS}^{*}\end{array}$ & $\begin{array}{c}18 / 1345(1.3 \%) \\
3 / 1345(0.2 \%) \\
54 / 1345(4.0 \%)\end{array}$ \\
\hline
\end{tabular}

Responding to a number of statements (table 6), most users would participate again or recommend testing to others. Further, most users were neutral to positive about their physician's knowledge of DTCtests, respectfulness towards their choices, and willingness to refer and assist in lifestyle changes. When asked about the test's influence on the patient-doctor or family relationships, the majority of responding users were neutral. Responses to the statement that doctors should more often point out positive aspects of DTC-tests or that the government should stimulate testing show less consensus.

\section{Outcomes of non-users}

Reasons for not undergoing medical testing for non-users can be found in table 3. A large proportion of non-users stated that they would undergo predictive testing if recommended by their physician (35.7\%) or if they would have symptoms (29.3\%). Reasons for not undergoing testing were that non-users thought testing was too commercialised, that they lacked knowledge of the tests, lacked symptoms, or that the costs were too high. Non-users in the DR-group were significantly more likely to not undergo testing because they found it too costly, too commercialised, unreliable, or because they lacked knowledge or symptoms. In comparison, non-users from the NPV-group were more likely to not participate in DTC-tests because of emotional or principal objections. The non-users of this group were more likely to consider testing if they have symptoms or if their physician would recommend it.

Responding to our statements (table 7), most non-users stand neutral to positive to participating in future predictive tests and the level of knowledge of their physician. As with users, non-users had mixed responses to whether physicians should point out positive aspects of DTC-tests and whether the government should stimulate uptake of DTC-tests.

\section{Uni- and multivariate logistic regression analyses}

Univariate logistic regression analyses were performed for all participants (main analysis) and for NPV- and DR-groups separately. Results can be found in tables 4 and 5 . In univariate analyses, included predictor variables were gender, age by category, level of education, religion, attitude toward testing, and for our main analysis the variable of belonging to NPV- or DR-groups.

Multivariate logistic regression analyses were performed for all participants (main analysis) and for the NPV-group separately. Since the DR-group had only one significant predictor variable from univariate analysis no multivariate analysis was performed. For the 
Table 1b: Baseline characteristics Comparing users and non-users

\begin{tabular}{|c|c|c|c|c|}
\hline & $\begin{array}{l}\text { Users } \\
(\mathrm{N}=75)\end{array}$ & $\begin{array}{l}\text { Non-users } \\
(\mathrm{N}=1270)\end{array}$ & Significance & $\begin{array}{c}\text { Total } \\
(\mathrm{N}=1345)\end{array}$ \\
\hline Male, $\mathrm{N}$ (\% of total in group) & $44 / 75(58.7 \%)$ & $525 / 1270(41.3 \%)$ & $\mathrm{P}=0.003^{*}$ & $569 / 1345(42.3 \%)$ \\
\hline 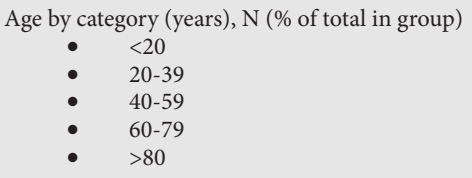 & $\begin{array}{c}0 / 75(0.0 \%) \\
20 / 75(26.7 \%) \\
31 / 75(41.3 \%) \\
23 / 75(30.7 \%) \\
1 / 75(1.3 \%)\end{array}$ & $\begin{array}{c}6 / 1270(0.5 \%) \\
148 / 1270(11.7 \%) \\
488 / 1270(38.4 \%) \\
592 / 1270(46.6 \%) \\
36 / 1270(2.8 \%)\end{array}$ & $\begin{array}{l}\mathrm{NS}^{* *} \\
\mathrm{P}=0.000^{*} \\
\mathrm{NS}^{*} \\
\mathrm{P}=0.007^{\star} \\
\mathrm{NS}^{* *}\end{array}$ & $\begin{array}{c}6 / 1345(0.5 \%) \\
168 / 1345(12.5 \%) \\
519 / 1345(38.6 \%) \\
615 / 1345(45.7 \%) \\
37 / 1345(2.8 \%)\end{array}$ \\
\hline 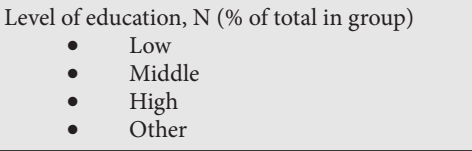 & $\begin{array}{c}7 / 75(9.3 \%) \\
30 / 75(40.0 \%) \\
38 / 75(50.7 \%) \\
0 / 75(0.0 \%)\end{array}$ & $\begin{array}{c}192 / 1270(15.1 \%) \\
537 / 1270(42.3 \%) \\
538 / 1270(42.4 \%) \\
3 / 1270(0.2 \%)\end{array}$ & $\mathrm{NS}^{* *}$ & $\begin{array}{c}199 / 1345(14.8 \%) \\
567 / 1345(42.2 \%) \\
576 / 1345(42.8 \%) \\
3 / 1345(0.2 \%)\end{array}$ \\
\hline $\begin{array}{ll}\text { Religion, } \mathrm{N} & \text { (\% of total in group) } \\
& \text { Christian } \\
& \circ \text { Roman Catholic } \\
& \text { o Protestant } \\
& \text { Humanistic } \\
: & \text { Islamic } \\
\text { - } & \text { Other } \\
\text { - None }\end{array}$ & $\begin{array}{l}50 / 75(66.7 \%) \\
6 / 75(8.0 \%) \\
44 / 75(58.7 \%) \\
2 / 75(2.7 \%) \\
0 / 75(0.0 \%) \\
3 / 75(4.0 \%) \\
20 / 75(26.7 \%)\end{array}$ & $\begin{array}{c}1067 / 1270(84.0 \%) \\
68 / 1270(5.4 \%) \\
999 / 1270(78.7 \%) \\
12 / 1270(0.9 \%) \\
2 / 1270(0.2 \%) \\
39 / 1270(3.1 \%) \\
150 / 1270(11.8 \%)\end{array}$ & $\begin{array}{l}\mathrm{P}=0.000^{*} \\
\mathrm{NS} S^{* *} \\
\mathrm{P}=0.000^{*} \\
\mathrm{NS}^{* *} \\
\mathrm{NS}^{* *} \\
\mathrm{NS}^{* *} \\
\mathrm{P}=0.000^{*}\end{array}$ & $\begin{array}{c}1117 / 1345(83.1 \%) \\
74 / 1345(5.5 \%) \\
1043 / 1345(77.6 \%) \\
14 / 1345(1.0 \%) \\
2 / 1345(0.2 \%) \\
42 / 1345(3.1 \%) \\
170 / 1345(12.6 \%)\end{array}$ \\
\hline $\begin{array}{cl}\text { Attitude, } \mathrm{N} \text { (\% of total in group) } \\
-\quad \text { Mainly positive } \\
-\quad \text { Positive and negative } \\
\text { - } \quad \text { Mainly negative } \\
\text { No opinion }\end{array}$ & $\begin{array}{c}16 / 75(21.3 \%) \\
50 / 75(66.7 \%) \\
9 / 75(12.0 \%) \\
0 / 75(0.0 \%)\end{array}$ & $\begin{array}{c}49 / 1270(3.9 \%) \\
815 / 1270(64.2 \%) \\
351 / 1270(27.6 \%) \\
55 / 1270(4.3 \%)\end{array}$ & $\begin{array}{c}\mathrm{P}=0.000^{* *} \\
\mathrm{NS} \\
\mathrm{P}=0.003^{*} \\
\mathrm{NS}^{* *}\end{array}$ & $\begin{array}{c}65 / 1345(4.8 \%) \\
865 / 1345(64.3 \%) \\
360 / 1345(26.8 \%) \\
55 / 1345(4.1 \%)\end{array}$ \\
\hline
\end{tabular}

main analysis, we included gender, age by category, religion, attitude, and belonging to NPV- or DR-groups as predictor variables. For the NPV-group, only gender and attitude were included. There was no relevant multicollinearity with all VIFs under 10. Box-Tidwell models showed that for all variables in multivariate analyses the linearity assumption was met. There was one significant interaction between predictor variables, namely between gender and attitude. Further exploration of this interaction showed that female participants were significantly less likely to opt for testing than male participants if they had a mixed attitude. There were no significant gender differences if participants had a positive or negative attitude towards testing.

In our main analysis and for the NPV-group, male gender and having a positive attitude towards testing remained significantly associated with opting for testing. Further, there was a significant correlation between being aged 20-39 years and uptake of DTC-tests in our main analysis.

\section{Survey amongst GPs}

\section{Baseline characteristics}

In total, 15 GPs aged 30 to 60 years were interviewed. Nine were male, 6 were non-religious, 9 were Christians, and they lived and practiced in a variety of environments (both urban and rural). On average, GPs are consulted weekly to monthly by patients who made use of health checks and are consulted about 3 times annually by patients who underwent a total body scan. Two GPs had been consulted by one or more patients who underwent genetic testing. With regards to their attitude towards DTC-tests, 9 GPs had a mixed or neutral attitude, 2 were mainly positive, and 4 were mainly negative.

\section{User-related outcomes of GPs}

If GPs were consulted pre-testing, patients did so mainly to explore their opinion of a DTC-test, to gain information, to prepare for testing, or to seek consent. During pre-testing consultation, 13 GPs informed patients on the pros and cons of a test, 8 generally discouraged testing, and 1 specifically explored the patient's motives for testing. Regarding reasons for not having been consulted before testing, 9 GPs suggested that patients do not seem to need their help before testing and 8 mentioned that patients expect a negative and critical response. Most GPs would prefer patients to consult them pretesting to engage in a deliberative process or to refer to a particular test.

After testing, most patients consulting their GP did so to get advice about further medical investigations, to seek reassurance, to inform their GP, or for advice. Based on their experiences, the interviewed GPs identified three groups of people who undergo DTC-tests: (1) those without health problems who want to prevent misfortune, (2) patients with worries about their health because of physical complaints or because of their family history, (3) those having experience in healthcare systems in which predictive medical tests are more commonplace, i.e. immigrants.

GPs noticed several consequences of DTC-tests, such as a felt need for referral for further medical care, an increased sense of responsibility for the wellbeing of oneself or one's family, lifestyle changes, fewer worries about oneself or one's family, and better insight in health risks. One GP mentioned a patient receiving an early diagnosis of cancer due to a total body scan. 
Theo A. Boer and Martijn N. van Rijswijk (2021) Direct-to-Consumer-Tests and the Patient-Doctor Relationship. A Survey amongst Users, NonUsers, and Physicians

Table 2: Outcomes of users

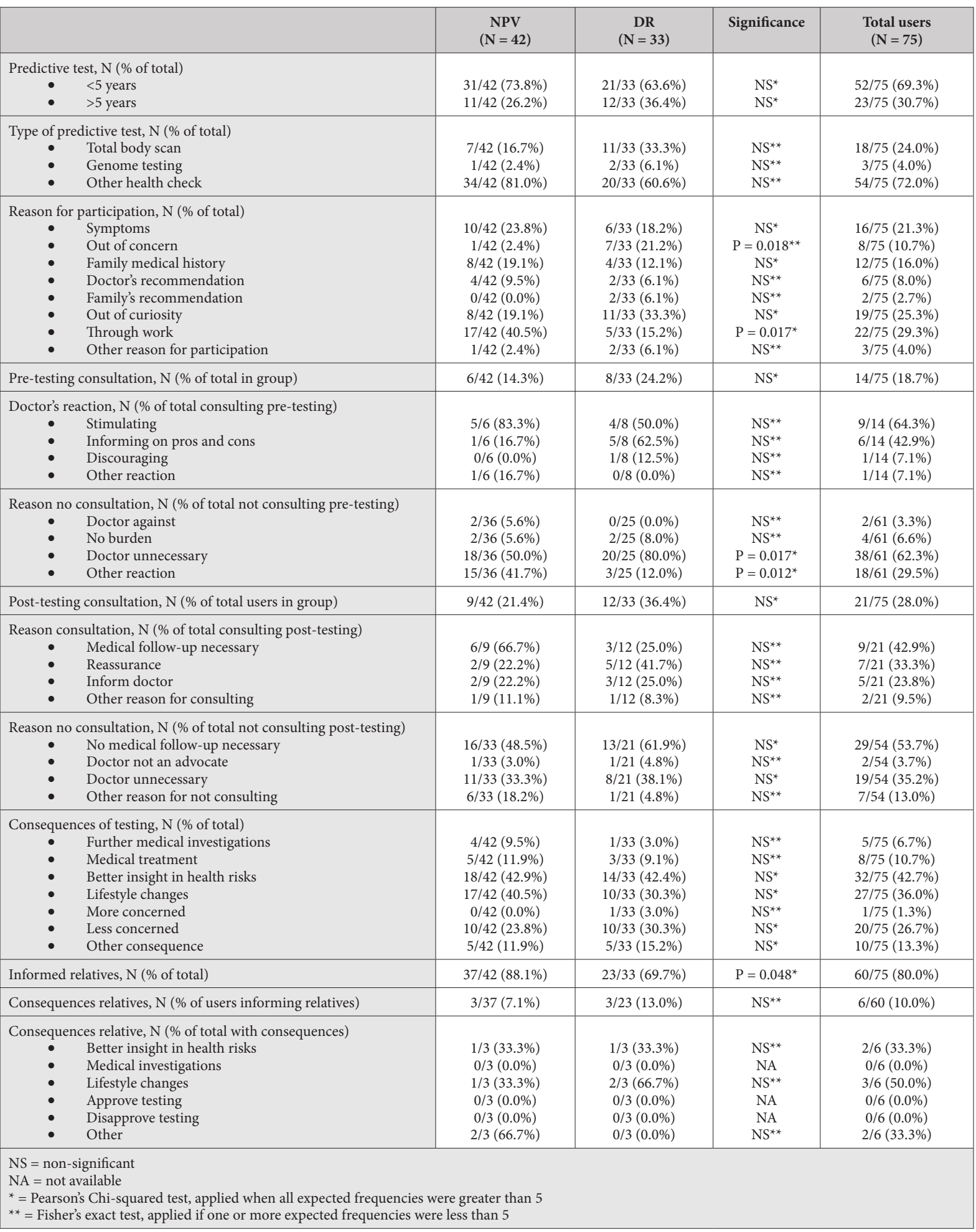

Regarding the patient-doctor relationship, 11 GPs affirmed that testing did not influence the patient-doctor relationship, 3 thought testing positively influenced the relationship as they felt patients became more aware of their autonomy and responsibility for their health, and 1 said it had a negative effect on the relationship. All the interviewed GPs affirm that doctors ought to be respectful and should try to understand a patient's motivation for testing, emphasising deliberative, interpretative, and informative models of the patientdoctor relationship. None of the GPs prefers a paternalistic model.

\section{Test-related outcomes of GPs}

On the level of the individual user, most GPs stated that many DTC-users have only partial knowledge of the value of a DTC-test and its results. They conclude that users should have received more 
Theo A. Boer and Martijn N. van Rijswijk (2021) Direct-to-Consumer-Tests and the Patient-Doctor Relationship. A Survey amongst Users, NonUsers, and Physicians

Table 3: Outcomes of non-users

\begin{tabular}{|c|c|c|c|c|}
\hline & $\begin{array}{c}\text { NPV } \\
(\mathrm{N}=987 ; 1 \text { missing })\end{array}$ & $\begin{array}{c}\text { DR } \\
(\mathrm{N}=283 ; 1 \text { missing })\end{array}$ & P-value & $\begin{array}{c}\text { Total non-users } \\
(\mathrm{N}=1268 ; 2 \text { missing })\end{array}$ \\
\hline $\begin{array}{ll}\text { Reason for not participating, } \mathrm{N} \text { (\% of total) } \\
\text { - } & \text { Lack of knowledge } \\
\text { - } & \text { Only if symptoms } \\
\text { - } & \text { Unreliability of tests } \\
\text { - } & \text { Only if recommended by doctor } \\
\text { - } & \text { Too commercial } \\
\text { - } & \text { Peer pressure } \\
\text { - } & \text { Practical limitations } \\
\text { - } & \text { Emotional objections } \\
\text { - } & \text { Principal objections } \\
\text { - } & \text { No symptoms } \\
\text { - } & \text { Other reason }\end{array}$ & $\begin{array}{c}192 / 986(19.5 \%) \\
302 / 986(30.6 \%) \\
66 / 986(6.7 \%) \\
371 / 986(37.6 \%) \\
205 / 986(20.8 \%) \\
1 / 986(0.1 \%) \\
98 / 986(9.9 \%) \\
15 / 986(1.5 \%) \\
48 / 986(4.9 \%) \\
144 / 986(14.6 \%) \\
203 / 986(20.6 \%) \\
66 / 986(6.7 \%) \\
\end{array}$ & $\begin{array}{c}75 / 282(26.6 \%) \\
69 / 282(24.5 \%) \\
33 / 282(11.7 \%) \\
82 / 282(29.1 \%) \\
86 / 282(30.5 \%) \\
0 / 282(0.0 \%) \\
100 / 282(35.5 \%) \\
10 / 282(3.6 \%) \\
5 / 282(1.8 \%) \\
5 / 282(1.8 \%) \\
54 / 282(19.2 \%) \\
12 / 282(4.3 \%) \\
\end{array}$ & $\begin{aligned} \mathrm{P}= & 0.010^{*} \\
\mathrm{P}= & 0.045^{*} \\
\mathrm{P}= & 0.006^{*} \\
\mathrm{P}= & 0.008^{*} \\
\mathrm{P}= & 0.001^{*} \\
& \mathrm{NS}^{* *} \\
\mathrm{P}= & 0.000^{*} \\
\mathrm{P}= & 0.031^{*} \\
\mathrm{P}= & 0.022^{*} \\
\mathrm{P}= & 0.000^{*} \\
& \mathrm{NS}^{*} \\
& \mathrm{NS}^{*}\end{aligned}$ & $\begin{array}{c}267 / 1268(21.1 \%) \\
371 / 1268(29.3 \%) \\
99 / 1268(7.8 \%) \\
453 / 1268(35.7 \%) \\
291 / 1268(23.0 \%) \\
1 / 1268(0.1 \%) \\
198 / 1268(15.6 \%) \\
25 / 1268(2.0 \%) \\
53 / 1268(4.2 \%) \\
149 / 1268(11.8 \%) \\
257 / 1268(20.3 \%) \\
78 / 1268(6.2 \%) \\
\end{array}$ \\
\hline
\end{tabular}

Table 4: Univariate Logistic Regression

\begin{tabular}{|c|c|c|c|c|c|c|c|}
\hline & & $\begin{array}{c}\text { aOR }(95 \% \mathrm{CI}) \\
\text { (Total) }\end{array}$ & P-value & $\begin{array}{l}\text { aOR (95\% CI) } \\
(\mathrm{NPV})\end{array}$ & P-value & $\begin{array}{c}\mathrm{aOR}(95 \% \mathrm{CI}) \\
\text { (DR) }\end{array}$ & P-value \\
\hline $\begin{array}{r}\text { Gender } \\
\bullet \\
\bullet\end{array}$ & $\begin{array}{l}\text { Male } \\
\text { Female }\end{array}$ & $\begin{array}{c}2.01 \text { (1.26-3.23) } \\
\text { Ref. }\end{array}$ & $\begin{array}{l}0.004 \\
\text { Ref. }\end{array}$ & $\begin{array}{c}2.08(1.11-3.88) \\
\text { Ref. }\end{array}$ & $\begin{array}{l}0.022 \\
\text { Ref. }\end{array}$ & $\begin{array}{c}1.59(0.76-3.33) \\
\text { Ref. }\end{array}$ & $\begin{array}{l}\text { NS } \\
\text { Ref. }\end{array}$ \\
\hline $\begin{array}{r}\text { Age by c } \\
\vdots \\
\vdots \\
\vdots\end{array}$ & $\begin{array}{l}\text { gory (years) } \\
<20 \\
20-39 \\
40-59 \\
60-79 \\
>80\end{array}$ & $\begin{array}{c}\text { NA } \\
3.48(1.86-6.50) \\
1.64(0.94-2.84) \\
\text { Ref. } \\
0.71(0.09-5.44)\end{array}$ & $\begin{array}{l}\text { NA } \\
0.000 \\
\text { NS } \\
\text { Ref. } \\
\text { NS }\end{array}$ & $\begin{array}{c}\text { NA } \\
1.72(0.49-6.04) \\
1.50(0.79-2.88) \\
\text { Ref. } \\
0.80(0.10-6.14)\end{array}$ & $\begin{array}{l}\text { NA } \\
\text { NS } \\
\text { NS } \\
\text { Ref. } \\
\text { NS }\end{array}$ & $\begin{array}{c}\text { NA } \\
2.64(0.93-7.47) \\
1.56(0.52-4.68) \\
\text { Ref. } \\
-\end{array}$ & $\begin{array}{l}\text { NA } \\
\text { NS } \\
\text { NS } \\
\text { Ref. } \\
-\end{array}$ \\
\hline $\begin{array}{r}\text { Level of } \\
\vdots \\
\vdots \\
\bullet\end{array}$ & $\begin{array}{l}\text { Ication } \\
\text { Low } \\
\text { Middle } \\
\text { High } \\
\text { Other }\end{array}$ & $\begin{array}{c}0.52(0.23-1.18) \\
0.79(0.48-1.30) \\
\text { Ref. } \\
\text { NA }\end{array}$ & $\begin{array}{l}\text { NS } \\
\text { NS } \\
\text { Ref. } \\
\text { NA }\end{array}$ & $\begin{array}{c}0.44(0.13-1.48) \\
0.59(0.30-1.14) \\
\text { Ref. } \\
\text { - }\end{array}$ & $\begin{array}{l}\text { NS } \\
\text { NS } \\
\text { Ref. } \\
-\end{array}$ & $\begin{array}{c}0.41(0.13-1.32) \\
1.03(0.47-2.24) \\
\text { Ref. } \\
\text { NA }\end{array}$ & $\begin{array}{l}\text { NS } \\
\text { NS } \\
\text { Ref. } \\
\text { NA }\end{array}$ \\
\hline $\begin{array}{r}\text { Religion } \\
\vdots \\
\vdots \\
\vdots\end{array}$ & $\begin{array}{l}\text { Christian } \\
\text { Humanistic } \\
\text { Islamic } \\
\text { Other } \\
\text { None }\end{array}$ & $\begin{array}{c}\text { Ref. } \\
3.56(0.78-16.32) \\
\text { NA } \\
1.64(0.49-5.49) \\
2.85(1.65-4.91)\end{array}$ & $\begin{array}{l}\text { Ref. } \\
\text { NS } \\
\text { NA } \\
\text { NS } \\
0.000\end{array}$ & $\begin{array}{c}\text { Ref. } \\
\text { NA } \\
- \\
0.83(0.11-6.25) \\
\text { NA }\end{array}$ & $\begin{array}{c}\text { Ref. } \\
\text { NA } \\
- \\
\text { NS } \\
\text { NA }\end{array}$ & $\begin{array}{c}\text { Ref. } \\
2.32(0.45-12.13) \\
\text { NA } \\
2.32(0.45-12.13) \\
1.77(0.78-4.05)\end{array}$ & $\begin{array}{l}\text { Ref. } \\
\text { NS } \\
\text { NA } \\
\text { NS } \\
\text { NS }\end{array}$ \\
\hline $\begin{array}{r}\text { Attitude } \\
\vdots \\
\vdots \\
\bullet\end{array}$ & $\begin{array}{l}\text { Mainly positive } \\
\text { Positive and negative } \\
\text { Mainly negative } \\
\text { No opinion }\end{array}$ & $\begin{array}{c}5.32(2.83-10.02) \\
\text { Ref. } \\
0.42(0.20-0.86) \\
\text { NA }\end{array}$ & $\begin{array}{l}0.000 \\
\text { Ref. } \\
0.018 \\
\text { NA }\end{array}$ & $\begin{array}{c}4.07(1.57-10.53) \\
\text { Ref. } \\
0.48(0.21-1.12) \\
\text { NA }\end{array}$ & $\begin{array}{l}0.004 \\
\text { Ref. } \\
\text { NS } \\
\text { NA }\end{array}$ & $\begin{array}{c}5.42(2.22-13.26) \\
\text { Ref. } \\
0.42(0.09-1.83) \\
\text { NA }\end{array}$ & $\begin{array}{l}0.000 \\
\text { Ref. } \\
\text { NS } \\
\text { NA }\end{array}$ \\
\hline $\begin{array}{r}\text { Researcl } \\
\bullet \\
\bullet\end{array}$ & $\begin{array}{l}\text { oup } \\
\text { NPV } \\
\text { DR }\end{array}$ & $\begin{array}{c}\text { Ref. } \\
2.74(1.70-4.41)\end{array}$ & $\begin{array}{l}\text { Ref. } \\
0.000\end{array}$ & $\begin{array}{l}- \\
-\end{array}$ & $\begin{array}{l}- \\
-\end{array}$ & - & - \\
\hline \multicolumn{8}{|c|}{$\begin{array}{l}\text { aOR = adjusted Odds Ratio } \\
\mathrm{CI}=\text { Confidence Interval } \\
\mathrm{NS}=\text { not significant } \\
\mathrm{NA}=\text { not applicable (no participants who underwent predictive medical testing) } \\
\text { - = not available (no participants in this category or non-relevant variable) }\end{array}$} \\
\hline
\end{tabular}

in-depth information to help them contextualise a test's results. More explicitly, GPs mentioned that DTC-tests tend to focus on one aspect of health and overlook the importance of other determinants of health, such as a patient's history and social context. Further, 8 GPs said that DTC-test providers give only scarce instructions on how to proceed if further medical follow-up may be indicated. Hereby, DTCtests saddle the doctor with the intricate task of guiding DTC-users in how to interpret the results and to determine what medical followup is needed. Some GPs stated that results of DTC-tests seem to be intentionally vague or inconclusive so as to instigate further medical tests to affirm or disprove their findings. Information on the risks, side effects, and costs was also reported to be lacking.
Asked about societal aspects, the interviewed GPs mentioned that DTC-tests burden existing healthcare systems with possibly unnecessary follow-up medical investigations and treatments. Some GPs indicated that the availability of DTC-tests leads to an increased medicalisation focusing on potential health hazards. Finally, some GPs expressed doubts whether DTC-tests really benefit patient autonomy. Given their commercial nature aimed at inviting people to participate, and given the limited information about the advantages and disadvantages, DTC-tests may even inhibit a well-informed, autonomous choice. All interviewed GPs asked for governmental regulation of DTC-tests, preventing the marketing of tests with limited clinical validity and utility, and of tests carrying significant 
Theo A. Boer and Martijn N. van Rijswijk (2021) Direct-to-Consumer-Tests and the Patient-Doctor Relationship. A Survey amongst Users, NonUsers, and Physicians

Table 5: Multivariate Logistic Regression

\begin{tabular}{|c|c|c|c|c|c|c|c|}
\hline & & $\begin{array}{c}\mathrm{aOR}(95 \% \mathrm{CI}) \\
\quad(\text { Total })\end{array}$ & P-value & $\begin{array}{c}\mathrm{aOR}(95 \% \mathrm{CI}) \\
(\mathrm{NPV})\end{array}$ & P-value & $\begin{array}{l}\mathrm{aOR}(95 \% \mathrm{CI}) \\
\text { (DR) }\end{array}$ & P-value \\
\hline $\begin{array}{r}\text { Gender } \\
\bullet\end{array}$ & $\begin{array}{l}\text { Male } \\
\text { Female }\end{array}$ & $\begin{array}{c}1.97(1.20-3.24) \\
\text { Ref. }\end{array}$ & $\begin{array}{l}0.007 \\
\text { Ref. }\end{array}$ & $\begin{array}{c}2.01(1.07-3.78) \\
\text { Ref. }\end{array}$ & $\begin{array}{l}0.030 \\
\text { Ref. }\end{array}$ & - & - \\
\hline $\begin{array}{r}\text { Age by } \\
\vdots \\
\vdots \\
\bullet\end{array}$ & $\begin{array}{l}\text { egory (years) } \\
<20 \\
20-39 \\
40-59 \\
60-79 \\
>80\end{array}$ & $\begin{array}{c}\text { NA } \\
2.40(1.15-5.00) \\
1.60(0.90-2.84) \\
\text { Ref. } \\
0.74(0.09-5.95)\end{array}$ & $\begin{array}{c}\text { NA } \\
0.020 \\
0.110 \\
\text { Ref. } \\
0.777\end{array}$ & - & - & - & - \\
\hline $\begin{array}{r}\text { Religion } \\
\dot{\bullet} \\
\vdots \\
\bullet\end{array}$ & $\begin{array}{l}\text { Roman Catholic } \\
\text { Protestant } \\
\text { Humanistic } \\
\text { Islamic } \\
\text { Other } \\
\text { None }\end{array}$ & $\begin{array}{c}0.89(0.27-2.97) \\
\text { Ref. } \\
1.93(0.32-11.58) \\
\text { NA } \\
1.28(0.35-4.74) \\
1.34(0.50-3.55)\end{array}$ & $\begin{array}{c}0.851 \\
\text { Ref. } \\
0.471 \\
\text { NA } \\
0.712 \\
0.560 \\
\end{array}$ & - & - & - & - \\
\hline $\begin{array}{r}\text { Attitude } \\
\bullet \\
\bullet\end{array}$ & $\begin{array}{l}\text { Mainly positive } \\
\text { Positive and negative } \\
\text { Mainly negative } \\
\text { No opinion }\end{array}$ & $\begin{array}{c}4.71(2.43-9.12) \\
\text { Ref. } \\
0.51(0.24-1.05) \\
\text { NA }\end{array}$ & $\begin{array}{c}0.000 \\
\text { Ref. } \\
0.069 \\
\text { NA }\end{array}$ & $\begin{array}{c}3.80(1.46-9.90) \\
\text { Ref. } \\
0.49(0.21-1.13) \\
\text { NA }\end{array}$ & $\begin{array}{c}0.006 \\
\text { Ref. } \\
0.093 \\
\text { NA }\end{array}$ & - & - \\
\hline $\begin{array}{r}\text { Researc } \\
\bullet\end{array}$ & $\begin{array}{l}\text { group } \\
\text { NPV } \\
\text { DR }\end{array}$ & $\begin{array}{c}\text { Ref. } \\
1.33(0.52-3.37)\end{array}$ & $\begin{array}{l}\text { Ref. } \\
0.553\end{array}$ & - & - & - & - \\
\hline
\end{tabular}

Table 6: Statements (users) about their doctor

\begin{tabular}{|c|c|c|c|c|c|c|}
\hline & $\begin{array}{c}\text { Totally } \\
\text { disagree }\end{array}$ & Disagree & Neutral & Agree & Totally Agree & $\begin{array}{c}\text { Not } \\
\text { applicable }\end{array}$ \\
\hline $\begin{array}{c}\text { (1) Doctor well informed }{ }^{* *} \\
\vdots \quad \text { DR } \\
\quad \text { NPV }\end{array}$ & $\begin{array}{l}2(2.7 \%) \\
0(0.0 \%) \\
2(4.8 \%)\end{array}$ & $\begin{array}{l}4(5.3 \%) \\
3(9.1 \%) \\
1(2.4 \%)\end{array}$ & $\begin{array}{l}16(21.3 \%) \\
8(24.2 \%) \\
8(19.1 \%)\end{array}$ & $\begin{array}{l}12(16.0 \%) \\
5(15.2 \%) \\
7(16.7 \%)\end{array}$ & $\begin{array}{l}7(9.3 \%) \\
6(18.2 \%) \\
1(2.4 \%)\end{array}$ & $\begin{array}{l}34(45.3 \%) \\
11(33.3 \%) \\
23(54.8 \%)\end{array}$ \\
\hline $\begin{array}{c}\text { (2) Doctor sufficient knowledge }{ }^{* *} \\
\qquad \quad \text { DR } \\
\qquad \quad \text { NPV }\end{array}$ & $\begin{array}{l}0(0.0 \%) \\
0(0.0 \%) \\
0(0.0 \%)\end{array}$ & $\begin{array}{l}6(8.0 \%) \\
2(6.1 \%) \\
4(9.5 \%)\end{array}$ & $\begin{array}{c}13(17.3 \%) \\
10(30.3 \%) \\
3(7.1 \%)\end{array}$ & $\begin{array}{c}17(22.7 \%) \\
7(21.2 \%) \\
10(23.8 \%)\end{array}$ & $\begin{array}{l}11(14.7 \%) \\
5(15.2 \%) \\
6(14.3 \%)\end{array}$ & $\begin{array}{c}28(37.3 \%) \\
9(27.3 \%) \\
19(45.2 \%)\end{array}$ \\
\hline $\begin{array}{c}\text { (3) Doctor respectful } \\
\qquad \quad \text { DR } \\
\bullet \quad \text { NPV }\end{array}$ & $\begin{array}{l}2(2.7 \%) \\
2(6.1 \%) \\
0(0.0 \%)\end{array}$ & $\begin{array}{l}2(2.7 \%) \\
0(0.0 \%) \\
2(4.8 \%)\end{array}$ & $\begin{array}{l}17(22.7 \%) \\
9(27.3 \%) \\
8(19.1 \%)\end{array}$ & $\begin{array}{l}9(12.0 \%) \\
4(12.1 \%) \\
5(11.9 \%)\end{array}$ & $\begin{array}{l}12(16.0 \%) \\
8(24.2 \%) \\
4(9.5 \%)\end{array}$ & $\begin{array}{l}33(44.0 \%) \\
10(30.3 \%) \\
23(54.8 \%)\end{array}$ \\
\hline $\begin{array}{l}\text { (4) Doctor willing to refer }{ }^{* *} \\
\qquad \quad \text { DR } \\
\text { NPV }\end{array}$ & $\begin{array}{l}0(0.0 \%) \\
0(0.0 \%) \\
0(0.0 \%)\end{array}$ & $\begin{array}{l}6(8.0 \%) \\
3(9.1 \%) \\
3(7.1 \%)\end{array}$ & $\begin{array}{c}11(14.7 \%) \\
7(21.2 \%) \\
4(9.5 \%)\end{array}$ & $\begin{array}{c}18(24.0 \%) \\
7(21.2 \%) \\
11(26.2 \%)\end{array}$ & $\begin{array}{l}11(14.7 \%) \\
6(18.2 \%) \\
5(11.9 \%)\end{array}$ & $\begin{array}{l}29(38.7 \%) \\
10(30.3 \%) \\
19(45.2 \%)\end{array}$ \\
\hline $\begin{array}{l}\text { (5) Doctor willing to assist in lifestyle changes }{ }^{* *} \\
\text { DR } \\
\text { NPV }\end{array}$ & $\begin{array}{l}2(2.7 \%) \\
1(3.0 \%) \\
1(2.4 \%)\end{array}$ & $\begin{array}{l}7(9.3 \% \\
3(9.1 \%) \\
4(9.5 \%)\end{array}$ & $\begin{array}{l}16(21.3 \%) \\
9(27.3 \%) \\
7(16.7 \%)\end{array}$ & $\begin{array}{l}10(13.3 \%) \\
5(15.2 \%) \\
5(11.9 \%)\end{array}$ & $\begin{array}{l}6(8.0 \%) \\
4(12.1 \%) \\
2(4.8 \%)\end{array}$ & $\begin{array}{l}34(45.3 \%) \\
11(33.3 \%) \\
23(54.8 \%)\end{array}$ \\
\hline $\begin{array}{c}\text { (6) Positive influence on doctor-patient relationship } \\
\qquad \quad \text { DR } \\
\text { NPV }\end{array}$ & $\begin{array}{l}1(1.3 \%) \\
0(0.0 \%) \\
1(2.4 \%)\end{array}$ & $\begin{array}{l}8(10.7 \%) \\
4(12.1 \%) \\
4(9.5 \%)\end{array}$ & $\begin{array}{l}31(41.3 \%) \\
15(45.5 \%) \\
16(38.1 \%)\end{array}$ & $\begin{array}{l}3(4.0 \%) \\
0(0.0 \% \\
3(7.1 \%)\end{array}$ & $\begin{array}{l}4(5.3 \%) \\
4(12.1 \%) \\
0(0.0 \%)\end{array}$ & $\begin{array}{l}28(37.3 \%) \\
10(30.3 \%) \\
18(42.9 \%)\end{array}$ \\
\hline $\begin{array}{c}\text { (7) Doctors should point out positive aspects more often } \\
\text { DR } \\
\quad \text { NPV }\end{array}$ & $\begin{array}{c}4(5.3 \%) \\
2(6.1 \%)^{* *} \\
2(4.8 \%)^{* *}\end{array}$ & $\begin{array}{c}12(16.0 \%) \\
2(6.1 \%)^{* *} \\
10(23.8 \%)^{* *}\end{array}$ & $\begin{array}{l}23(30.7 \%) \\
13(39.4 \%)^{* *} \\
10(23.8 \%)^{* *}\end{array}$ & $\begin{array}{l}20(26.7 \%) \\
5(15.2 \%)^{* *} \\
15(35.7 \%)^{* *}\end{array}$ & $\begin{array}{l}12(16.0 \%) \\
9(27.3 \%)^{* *} \\
3(7.1 \%)^{* *}\end{array}$ & $\begin{array}{l}4(5.3 \%) \\
2(6.1 \%)^{* *} \\
2(4.8 \%)^{* *}\end{array}$ \\
\hline $\begin{array}{l}\text { (8) Testing had positive influence on family relations* } \\
\text { DR } \\
\text { NPV }\end{array}$ & $\begin{array}{l}3(4.0 \%) \\
0(0.0 \%)^{* *} \\
3(7.1 \%)^{* *}\end{array}$ & $\begin{array}{l}7(9.3 \%) \\
3(9.1 \%)^{* *} \\
4(9.5 \%)^{* *}\end{array}$ & $\begin{array}{l}26(34.7 \%) \\
11(33.3 \%)^{* *} \\
15(35.7 \%)^{* *}\end{array}$ & $\begin{array}{l}9(12.0 \%) \\
7(21.2 \%)^{* *} \\
2(4.8 \%)^{* *}\end{array}$ & $\begin{array}{c}5(6.7 \%) \\
5(15.2 \%)^{* *} \\
0(0.0 \%)^{* *}\end{array}$ & $\begin{array}{l}25(33.3 \%) \\
7(21.2 \%)^{* *} \\
18(42.9 \%)^{* *}\end{array}$ \\
\hline $\begin{array}{c}\text { (9) Would participate again } \\
\bullet \quad \text { DR } \\
\text { NPV }\end{array}$ & $\begin{array}{l}1(1.3 \%) \\
0(0.0 \%) \\
1(2.4 \%)\end{array}$ & $\begin{array}{l}5(6.7 \%) \\
2(6.1 \%) \\
3(7.1 \%)\end{array}$ & $\begin{array}{l}20(26.7 \%) \\
7(21.2 \%) \\
13(31.0 \%)\end{array}$ & $\begin{array}{l}31(41.3 \%) \\
16(48.5 \%) \\
15(35.7 \%)\end{array}$ & $\begin{array}{l}15(20.0 \%) \\
8(24.2 \%) \\
7(16.7 \%)\end{array}$ & $\begin{array}{l}3(4.0 \%) \\
0(0.0 \%) \\
3(7.1 \%)\end{array}$ \\
\hline $\begin{array}{l}\text { (10) Recommend to others }{ }^{* *} \\
\text { DR } \\
\text { - NPV }\end{array}$ & $\begin{array}{l}2(2.7 \%) \\
1(3.0 \%) \\
1(2.4 \%)\end{array}$ & $\begin{array}{l}6(8.0 \%) \\
1(3.0 \%) \\
5(11.9 \%)\end{array}$ & $\begin{array}{l}29(38.7 \%) \\
12(36.4 \%) \\
17(40.5 \%)\end{array}$ & $\begin{array}{l}24(32.0 \%) \\
11(33.3 \%) \\
13(31.0 \%)\end{array}$ & $\begin{array}{l}11(14.7 \%) \\
7(21.2 \%) \\
4(9.5 \%)\end{array}$ & $\begin{array}{l}3(4.0 \%) \\
1(3.0 \%) \\
2(4.8 \%)\end{array}$ \\
\hline $\begin{array}{c}\text { (12) Government should stimulate testing** } \\
\text { • DR } \\
\text { NPV }\end{array}$ & $\begin{array}{l}3(4.0 \%) \\
1(3.0 \%) \\
2(4.8 \%)\end{array}$ & $\begin{array}{c}15(20.0 \%) \\
5(15.2 \%) \\
10(23.8 \%)\end{array}$ & $\begin{array}{c}20(26.7 \%) \\
12(36.4 \%) \\
8(19.1 \%)\end{array}$ & $\begin{array}{c}25(33.3 \%) \\
8(24.2 \%) \\
17(40.5 \%)\end{array}$ & $\begin{array}{c}10(13.3 \%) \\
7(21.2 \%) \\
3(7.1 \%)\end{array}$ & $\begin{array}{l}2(2.7 \%) \\
0(0.0 \%) \\
2(4.8 \%)\end{array}$ \\
\hline
\end{tabular}


Table 7: Statements (non-users)

\begin{tabular}{|c|c|c|c|c|c|c|}
\hline & $\begin{array}{c}\text { Totally } \\
\text { disagree }\end{array}$ & Disagree & Neutral & Agree & $\begin{array}{l}\text { Totally } \\
\text { Agree }\end{array}$ & $\begin{array}{c}\text { Not } \\
\text { applicable }\end{array}$ \\
\hline $\begin{array}{l}\text { (1) Doctor well informed }{ }^{* *} \\
\text { - DR } \\
\text { - NPV }\end{array}$ & $\begin{array}{c}29(2.3 \%) \\
5(1.8 \%) \\
24(2.4 \%)\end{array}$ & $\begin{array}{l}56(4.4 \%) \\
20(7.1 \%) \\
36(3.7 \%)\end{array}$ & $\begin{array}{l}620(48.9 \%) \\
140(49.7 \%) \\
480(48.7 \%)\end{array}$ & $\begin{array}{c}245(19.3 \%) \\
52(18.4 \%) \\
193(19.6 \%)\end{array}$ & $\begin{array}{l}63(5.0 \%) \\
17(6.0 \%) \\
46(4.7 \%)\end{array}$ & $\begin{array}{r}255(20.1 \%) \\
48(17.0 \%) \\
207(21.0 \%)\end{array}$ \\
\hline $\begin{array}{l}\text { (2) Doctors should point out positive aspects more often } \\
\qquad \quad \text { DR } \\
\text { - } \\
\text { NPV }\end{array}$ & $\begin{array}{c}185(14.6 \%) \\
20(7.1 \%)^{*} \\
165(16.7 \%)^{*}\end{array}$ & $\begin{array}{c}400(31.6 \%) \\
55(19.5 \%)^{\star} \\
345(35.0 \%)^{*}\end{array}$ & $\begin{array}{c}432(34.1 \%) \\
104(36.9 \%)^{* *} \\
328(33.3 \%)^{* *}\end{array}$ & $\begin{array}{c}190(15.0 \%) \\
82(29.1 \%)^{*} \\
108(11.0 \%)^{*}\end{array}$ & $\begin{array}{l}34(2.7 \%) \\
16(5.7 \%)^{\star} \\
18(1.8 \%)^{\star}\end{array}$ & $\begin{array}{l}27(2.1 \%) \\
5(1.8 \%)^{* *} \\
22(2.2 \%)^{* *}\end{array}$ \\
\hline $\begin{array}{c}\text { (3) Would consider testing* } \\
\qquad \quad \text { DR } \\
\text { NPV }\end{array}$ & $\begin{array}{c}150(11.8 \%) \\
27(9.6 \%)^{* *} \\
123(12.5 \%)^{* *}\end{array}$ & $\begin{array}{c}226(17.8 \%) \\
29(10.3 \%)^{*} \\
197(20.0 \%)^{*}\end{array}$ & $\begin{array}{c}348(27.4 \%) \\
70(24.8 \%)^{\star *} \\
278(28.2 \%)^{\star *}\end{array}$ & $\begin{array}{l}447(35.3 \%) \\
123(43.6 \%)^{*} \\
324(32.9 \%)^{*}\end{array}$ & $\begin{array}{l}63(5.0 \%) \\
28(9.9 \%)^{\star} \\
35(3.6 \%)^{\star}\end{array}$ & $\begin{array}{c}34(2.7 \%) \\
5(1.8 \%)^{* *} \\
29(2.9 \%)^{* *}\end{array}$ \\
\hline $\begin{array}{l}\text { (4) Government should stimulate testing } \\
\text { DR } \\
\text { NPV }\end{array}$ & $\begin{array}{l}287(22.6 \%) \\
31(11.0 \%)^{*} \\
256(26.0 \%)^{*}\end{array}$ & $\begin{array}{l}427(33.7 \%) \\
69(24.5 \%)^{*} \\
358(36.3 \%)^{*}\end{array}$ & $\begin{array}{c}351(27.7 \%) \\
86(30.5 \%)^{* *} \\
265(26.9 \%)^{\star *}\end{array}$ & $\begin{array}{l}139(11.0 \%) \\
74(26.2 \%)^{*} \\
65(6.6 \%)^{*}\end{array}$ & $\begin{array}{l}38(3.0 \%) \\
17(6.0 \%)^{*} \\
21(2.1 \%)^{*}\end{array}$ & $\begin{array}{l}26(2.1 \%) \\
5(1.8 \%)^{* *} \\
21(2.1 \%)^{* *}\end{array}$ \\
\hline
\end{tabular}

risk of harm or discomfort. Further, available DTC-tests should be monitored to guarantee a continuous evaluation of their benefits and harms. Reflecting on their own role, GPs think that physicians should emphasise 1) the possibility of performing health checks themselves, and 2) their potential as interlocutors and sources of information to help patients balance the advantages and disadvantages of testing before deciding whether to participate, emphasising deliberative, interpretative, and informative models of the patient-doctor relationship.

\section{Focus group discussion}

Our focus group included two GPs, both counselling several patients yearly about the results of health checks, two DTC-users (one having had 2 total body scans and one having had a genetic test), and one interested non-user. In their discussion the participants, despite some different views, affirmed several findings from our surveys. Most importantly, they valued an open and respectful patientdoctor relationship, irrespective of the patient's and the physician's convictions. Participants agreed on the value of (1) a physician being open to discuss DTC-tests and willing to inform about their different medical characteristics, (2) shared decision-making, (3) recognition of the importance of a patient's responsibility in exploring health risks and preventing illness, (4) openness to find ways to reach these objectives by less invasive means, and (5) recognition of the fact that some tests may cause unnecessary concerns.

\section{Discussion}

\section{DTC-tests}

We found that 75 of 1,345 respondents (5.6\%) underwent a DTCtest, mainly health checks and total body scans, of which most within the last 5 years. Multivariate logistic regression analysis showed that, for our total research group, male gender, younger age (20-39 years), and having a positive attitude towards DTC-tests were significantly correlated with the uptake of DTC-tests. Focusing on the DR-group, univariate logistic regression analysis showed that only having a positive attitude towards DTC-tests significantly correlated with the uptake of DTC-tests. If we extrapolate our results to the Dutch population, counting 17.4 million in 2020 , approximately 900,000 people will have participated in DTC-tests, with more than 200,000 people having had a total body scan. Given the positive attitude towards future testing that we found amongst users and non-users, combined with the importance of lifestyle, prevention, and patient autonomy, we can expect these numbers to rise in the coming decades. Based on our results, the rise of DTC-users can be expected to be greatest among those with a positive attitude towards these tests and possibly greater among younger, non-religious men.

Some of this stands in contrast to earlier research of Hoebel et al and Dryden et al, who found that participants of adult health checks generally were of older age $[16,17]$ and more likely to be female [17]. However, these studies do not focus on DTC-tests, but include predictive tests offered by regular healthcare systems. Tests offered through healthcare schemes are more likely to invite the elderly, as they are at increased risk for (chronic) disease. Moreover, our results may indicate that younger, male respondents prefer to decide for themselves whether to partake in health checks or are more likely to be offered DTC-tests through work, sport clubs, etc. As reviewed by Dryden, many studies show that people of lower socioeconomic status are less likely to use health checks. This is a finding we could not reproduce with our data (level of education) when correcting for other factors. We did not focus on employment, height of income, marital status, or ethnicity.

Main reasons for participation in DTC-tests were the availability through one's employer, presence of symptoms, curiosity, and concern. Of 1,268 non-users a large proportion responded they would undergo DTC-tests either upon recommendation by their physician or in case of symptoms. These findings are in accordance with existing literature, as reviewed by Dryden et al [17] and Stol et al. [18] Studies included in these reviews show that people participate in health checks for health related and non-health related reasons. Among the first are the goals of informing on and monitoring of one's health status, reassurance, preventing (advanced stages of) disease, and health improvement. This included testing out of concern or due to symptoms or family history. Examples of non-health related reasons include preferential circumstances lowering the threshold for testing, such as availability during a workday and an invitation from colleagues or family members. In contrast to these studies, we did not find that the intention to establish contact with a physician was a reason for testing. 
In our study, main reasons for not participating in DTC-tests were the absence of symptoms, their commercial nature, a lack of knowledge of DTC-tests, expected costs, or principal objections. Likewise, Stol et al found that reasons for people not to use health checks were the absence of physical complaints, distrust of tests, the conviction that health checks are unfit in a presymptomatic stage, busy schedules, lack of knowledge, and related costs. In contrast to our study, both reviews mention that people also refrain from testing because they already had a health check, do not want to burden health systems, put low priority on healthcare or their health, were less self-sufficient, felt less in control of their health, or had problems with accessibility or transport. We did not include these options in our structured questionnaire but they may also have been reasons for non-usage.

From our results, it cannot be concluded whether or not DTCtests offer direct health benefits. A systematic review by Krogsbøll et al [19], which included 14 randomised controlled trials with 182,880 participants, attempted to compare benefits of health checks in adult populations. Aggregating the evidence of these trials did not show a decrease in morbidity, total mortality (11 trials), cardiovascular mortality ( 8 trials), or cancer mortality ( 8 trials). Two trials found an increase in new diagnoses per participant in screened populations, mainly hypertension and hypercholesterolemia. Further, two trials reported an increase in the prescription of antihypertensive drugs in screened populations [19]. A similar review by Si et al [20] looked at surrogate outcomes such as cholesterol and blood pressure levels. They did so stating most studies of health checks are too short to validly measure differences in morbidity and mortality rates. Their review shows that health checks offered by GPs significantly improve these surrogate outcomes [20]. Therefore, DTC-tests may lead to longterm health benefits.

DTC-tests may also enhance health through an increased awareness of one's health status and of the need for a healthy lifestyle, as was found in our study. Other studies found that health checks for cardiovascular disease led to an improvement in self-reported physical activity [21], a more healthy diet behaviour [21], a decline in self-reported alcohol consumption [22], and positive dietary changes [22]. However, these effects could in principle be realised without DTC-tests, for example through public awareness campaigns. Further, some studies did not find a lasting improvement towards a healthier lifestyle after using DTC-tests [23], questioning their longterm effects. Moreover, these benefits should be balanced against the possibility that DTC-tests may lead to unnecessary concern, overmedicalisation, and over-responsibilisation [8]. The latter refers to the idea that we are personally responsible for our health, blaming the ill for much of their health status.

Finally, DTC-tests carry a risk of overdiagnosis and overtreatment. After all, inconclusive or abnormal results may prompt further medical investigations and treatment which in hindsight may turn out to have been unnecessary. In our study, a small proportion of DTCusers underwent additional investigations (6.7\%), or received medical treatment $(10.7 \%)$. It is unknown to us what the indications were and whether this led to health benefits or caused harm. Given the risks of DTC-tests, all our interviewed GPs stressed the importance of governmental regulation and monitoring of DTC-tests to ensure their quality and health benefits.

\section{Patient-doctor relationship}

Most DTC-users and all but one of the interviewed GPs stated that DTC-tests had a neutral to positive impact on patient-doctor relationships. Users were neutral to positive about their physician's knowledge of DTC-tests, respectfulness towards their choices, and willingness to refer or assist in lifestyle changes. GPs emphasised the importance of non-paternalistic models of the patient-doctor relationship, mainly the deliberative and interpretative models, guiding a patient in deciding on the uptake of a DTC-test or referring for a particular test themselves. However, most DTC-users did not consult their physician before or after testing, the main reasons being that they needed no extra expertise (this underscores the value of autonomy) and that there was no indication for medical follow-up. This might show that DTC-users either think of DTC-tests as being of little importance, not worth mentioning to their GP, or value their patient-doctor relationship less highly than GPs do. We assume that the first is more likely. We conclude this from the fact that normal (i.e., negative) test results were separately mentioned as a major reason for not consulting one's physician.

Among interviewed GPs, over half expected the prospect of an opposing attitude to be a major reason for their patients not to consult their physician. In our patient survey, however, we found that this was a reason for only a small minority of users: whilst only 1 of 14 DTC-users who had consulted their doctor before testing stated to have received a discouraging reaction, 8 of 15 GPs said to have been discouraging. This might imply a perceived difference between how physicians reflect on themselves compared to how a patient reflects on their physician.

To maintain their role as interlocutor or source of information, physicians should ensure adequate knowledge of DTC-tests and show that they are willing to be involved prior to and after testing. Doctor and patient alike could benefit from the effects of this openness for their relationship. However, this requires clear information regarding DTC-tests and their characteristics, benefits, harms and costs.

\section{Limitations}

One limitation of our research is that about $75 \%$ of respondents were recruited from the Dutch Patient Association NPV, whose members have a predominantly Protestant Christian background. For compensation we performed and compared separate analyses of NPV- and DR-research groups, assuming our DR-group to better represent the Dutch population. A second limitation is the relatively small group of DTC-users: although a number of 75 users $(5.6 \%$ of our research population) does provide valuable material, research with a larger group of users is commendable. A third limitation is our use of semi-structured questionnaires, thereby limiting the options for respondents to choose and possibly missing unique insights. This limitation was mitigated by the fact that almost all questions included an 'other'-option. A fourth limitation of our study is its cross-sectional design, which impedes follow-up and thus evaluation of possible benefits and harms of DTC-tests, and risks recall bias as it 
Theo A. Boer and Martijn N. van Rijswijk (2021) Direct-to-Consumer-Tests and the Patient-Doctor Relationship. A Survey amongst Users, NonUsers, and Physicians

depends on the memory of respondents. Therefore, further research into DTC-tests should preferably include prospective study designs or randomised controlled trials.

\section{Conclusion}

We found that $5.6 \%$ of respondents have used DTC-tests, particularly health checks and total body scans, with a tendency to increased use and an apparent growth potential. Uptake of DTC-tests was significantly correlated with having a positive attitude towards DTC-tests, male gender, and younger age in our main analysis, and with a positive attitude in our most representative subgroup analysis. Generally, DTC-tests had a neutral to positive influence on patientdoctor relationships. However, regarding this relationship there were discrepancies between responses of DTC-users and GPs. In particular, most DTC-users saw no need to consult their physician either before or after testing, whilst GPs stressed the importance of consultation for guidance or referral. Therefore, DTC-tests seem to challenge patient-doctor relationships by enabling patients to undergo medical tests without interference by their physician. Patient autonomy thus continues to gain importance within the medical field.

\section{Funding and organisation}

The study was funded by The Netherlands Organisation for Health Research and Development (ZonMw), an independent governmental research platform, and supervised by an interdisciplinary, independent board of scientists, GPs, and patients. The project was initiated by the Prof.dr. G.A. Lindeboom Instituut (PLI) for Medical Ethics.

\section{Impact statement}

We certify that this research is novel. The raw research results can be accessed in a VU-University database. A preliminary report of this research, without the analyses conducted here, was published as Boer TA, Einerhand SMH, De Haas-de Vries JA, Van Rijswijk MN. Komt een test bij de dokter. Amsterdam: Buijten \& Schipperheijn; 2018.

\section{References}

1. Gefenas E, Cekanauskaite A, Tuzaite E, Dranseika V, Characiejus D. et al. (2011) Does the 'New Philosophy' in Predictive, Preventive and Personalised Medicine Require New Ethics? EPMA J. Jun;2(2):141-7. [cross-ref]

2. Thompson S, Tonelli M. General Health Checks in Adults for Reducing Morbidity and Mortality from Disease [Editorial]. Cochrane Database Syst Rev. 2012;10.

3. Predictive Medicine [Internet]. Nature. [cited 2018 Apr 20]. Available from: https:// www.nature.com/subjects/predictive-medicine.

4. Wilson JMG, Jungner G. Principles and Practice of Screening for Disease. Geneva: World Health Organization; 1968. 164 p.

5. Bradley WG, Golding SG, Herold CJ, Hricak H, Krestin GP, Lewin JS, et al. (2009 \& 2011) Globalization of P4 Medicine: Predictive, Personalized, Preemptive, and Participatory-Summary of the Proceedings of the Eighth International Symposium of the International Society for Strategic Studies in Radiology, August 27-29. Radiology. 258(2):571-82. [cross-ref]
6. Fenton JJ, Deyo RA. (2003) Patient Self-Referral for Radiologic Screening Tests: Clinical and Ethical Concerns. J Am Board Fam Pract. 16(6):494-501. [cross-ref]

7. Bijlsma M, Rendering A, Chin-On N, Debska A, von Karsa L, Knöpnadel J, et al.(2014) Quality Criteria for Health Checks: DEVELOPMENT of a European Consensus Agreement. Prev Med (Baltim). 67:238-41.

8. Stol YH, Schermer MHN, Asscher ECA. (2016) Omnipresent Health Checks May Result in Over-Responsibilization. Public Health Ethics. phw034. [cross-ref]

9. Health Council of the Netherlands. Screening: Between Hope and Hype. The Hague: Health Council of the Netherlands; 2008.

10. Levitt DM.(2001) Let the Consumer Decide? The Regulation of Commercial Genetic Testing. J Med Ethics. Dec;27(6):398-403. [cross-ref]

11. Savard J, Mooney-Somers J, Newson AJ, Kerridge I. (2014) Australians' Knowledge and Perceptions of Direct-to-Consumer Personal Genome Testing. Intern Med J. Jan;44(1):27-31. [cross-ref]

12. Marshall KG.(1996 Jul) Prevention. How Much Harm? How Much Benefit? 3. Physical, Psychological and Social Harm. CMAJ. 155(2):169-76. [cross-ref]

13. Emanuel EJ, Emanuel LL.(1992) Four Models of the Physician-Patient Relationship. JAMA - J Am Med Assoc. 267(16):2221-6.

14. Beauchamp TL, Childress JF. (2013) Principles of Biomedical Ethics. 7th ed. New York: Oxford University Press; $1-459 \mathrm{p}$.

15. Saunders B, Sim J, Kingstone T, Baker S, Waterfield J, Bartlam B, et al. (2017) Saturation in Qualitative Research: Exploring Its Conceptualization and Operationalization. Qual Quant.1-15. [cross-ref]

16. Hoebel J, Starker A, Jordan S, Richter M, Lampert T. (2014) Determinants of Health Check Attendance in Adults: Findings from the Cross-Sectional German Health Update (GEDA) Study. BMC Public Health. 14(1):1-12

17. Dryden R, Williams B, McCowan C, Themessl-Huber M. (2012) What Do We Know about Who Does and Does Not Attend General Health Checks? Findings from a Narrative Scoping Review. BMC Public Health. Dec 31;12(1):723. [cross-ref]

18. Stol Y, Asscher E, Schermer M.(2016) Reasons to Participate or Not to Participate in Cardiovascular Health Checks: A Review of the Literature. Public Health Ethics. 9(3):301-11.

19. Krogsboll LT, Jorgensen KJ, Gronhoj Larsen C, Gotzsche PC. (2012) General Health Checks in Adults for Reducing Morbidity and Mortality from Disease: Cochrane Systematic Review and Meta-Analysis. Bmj. 345(e7191). [cross-ref]

20. Si S, Moss JR, Sullivan TR, Newton SS, Stocks NP. (2014) Effectiveness of General Practice-Based Health Checks: A Systematic Review and Meta-Analysis. Br J Gen Pract. 64(618):47-53. [cross-ref]

21. Amoroso C, Harris MF, Ampt A, Laws RA, McKenzie S, Williams AM, et al. (2009) The 45 Year Old Health Check: Feasibility and Impact on Practices and Patient Behaviour. Aust Fam Physician. 38(5):358-62. [cross-ref]

22. Hanlon P, McEwen J, Carey L, Gilmour H, Tannahill C, Tannahill A, et al.(1995) Health Checks and Coronary Risk: Further Evidence from a Randomised Controlled Trial. BMJ. 311(7020):1609-13.

23. Griffiths C, Cooke S, Toon P. (1994) Registration Health Checks: Inverse Care in the Inner City? Br J Gen Pract. 44(382):201-4. [cross-ref]

\section{Citation:}

M.N. van Rijswijk and T.A. Boer (2021) Direct-to-Consumer-Tests and the Patient-Doctor Relationship. A Survey amongst Users, Non-Users, and Physicians. Prev Med Epid Public Heal Volume 2(2): 1-11. 